\title{
A new Amazonian species from the Drosophila annulimana species group (Diptera, Drosophilidae)
}

\author{
Marco S. Gottschalk¹, Marlúcia B. Martins², Catarina de L. B. Praxedes² \& Hermes F. de Medeiros ${ }^{3}$
}

\begin{abstract}
${ }^{1}$ Laboratório de Entomologia, Instituto de Ciências Biológicas, Universidade Federal do Rio Grande. Av. Itália, km 8, Campus Carreiros, 96. 203-900 Rio Grande-RS, Brasil.gotts007@yahoo.com, marcogottschalk@furg.br

${ }^{2}$ Laboratório de Ecologia de Insetos, Coordenação de Zoologia, Museu Paraense Emilio Goeldi. Av. Perimetral, 1901, 66077-830 Belém-PA, Brasil. marlucia@museu-goeldi.br, cpraxedes@museu-goeldi.br

${ }^{3}$ Universidade Federal do Pará, Campus Universitário de Altamira. Rua José Porfírio, 2515, 68372-010 Altamira-PA, Brasil. hermes@ufpa.br
\end{abstract}

\begin{abstract}
A new Amazonian species from the Drosophila annulimana species group (Diptera, Drosophilidae). Drosophila caxiuana sp. nov., Drosophila subgenus, is described and illustrated. This new species was collected in the Amazonian Biome (Caquajó river, Portel, Pará, Brazil) and is an atypical species to the group due the unusual morphology of the male terminalia.

KEYWORDS. Brazil; Drosophilinae; male terminalia; new species; taxonomy.

RESUMO. Uma nova espécie amazônica pertencente ao grupo de espécies Drosophila annulimana (Diptera, Drosophilidae). Drosophila caxiuana sp. nov., subgênero Drosophila, é descrita e ilustrada. Essa nova espécie foi coletada no Bioma Amazônico (Rio Caquajó, Portel, Pará, Brasil) e é uma espécie atípica deste grupo devido à morfologia incomum da terminália masculina.

PALAVRAS-CHAVE. Brasil; Drosophilinae; espécie nova; terminália masculina, taxonomia.
\end{abstract}

The Drosophila annulimana species group presently comprises 16 Neotropical species (Vilela 1985; Pereira \& Vilela 1987; Vela \& Rafael 2005), mostly sibling species, with spotted thorax. In faunistic surveys made with banana baits to attract imagoes, the $D$. annulimana species group is frequently found although at rather low densities (Martins 2001; Tidon 2006; Gottschalk et al. 2007; Döge et al. 2008). Apparently, this group is rather found in wet forests (Pereira \& Vilela 1987; Döge et al. 2008), although D. ararama Pavan \& Cunha, 1947 and D. schineri Pereira \& Vilela, 1987 have been sampled in areas of open vegetation, as brushwood and cerrado (Gottschalk et al. 2007). Basic biological information on breeding and feeding sites of the D. annulimana species group is largely lacking.

Taxonomy of the $D$. annulimana species group, on the other hand, is well resolved; besides the original descriptions of species, many additional characterizations and redescriptions have been done, making their identification easy (Breuer \& Pavan 1950; Vilela \& Val 1983; Vilela \& Pereira 1985; Vilela \& Bächli 1990). It seems however that more species are still to be found. We describe in this paper a new species of Drosophila belonging to D. annulimana species group, from the Caxiuanã National Forest, state of Pará in the Eastern Amazon.

\section{MATERIAL AND METHODS}

Three male and two female specimens from Drosophila caxiuana sp. nov., collected with banana baits in Caxiuanã National Forest, Portel municipality, state of Pará, Brazil, were analyzed. These specimens were conserved in ethanol $70 \%$ and before double-mounted with micropins, they were dried with an ethanol series $(70 \%, 75 \%, 80 \%, 85 \%, 90 \%, 95 \%$ and $100 \%$ ethanol). Male terminalia were treated and dissected following Bächli et al. (2004). The terminology for general morphology and male and female terminalia follows Bächli et al. (2004). Measurements are indicated by respective averages followed by the ranges in parentheses. They were performed with a reticle adjusted to an optical stereomicroscope (Zeiss Stemi V.11), in dried mounted specimens. Illustrations were drawn using a camara lucida (magnification of $1.8 \mathrm{x}$ ) attached to an optical microscope with a $20 \mathrm{x}$ objective lens and a 10x ocular lens. Photos were taken with a multifocal stereomicroscope (Zeiss Discovery V.20).

The studied specimens are deposited in Museu Paraense Emílio Goeldi (MPEG), Belém, Brazil.

$$
\text { Drosophila Fallén, } 1823
$$

\section{Drosophila annulimana species group}

Drosophila caxiuana sp. nov.

(Figs. 1-20)

Type series (MPEG): Male holotype labelled "Drosophila caxiuana Gottschalk et al. HOLÓTIPO M / Brasil - PA - Portel; FLONA Caxiuanã PPBio; $1^{\circ} 57^{\prime} 36,76^{\prime \prime}$ 'S, 51³8'16,00”W; Código U07003; Data: 30.V.2008 a 03.VI.2008; Col: Hermes F. de Medeiros". Two males paratypes labelled "Drosophila caxiuana Gottschalk et al.; PARATYPE M / Brasil - PA - Portel; FLONA Caxiuanã - PPBio; 157’36,76”'S, 51³8’16,00”W; Código U07003; Data: 30.V.2008 a 03.VI.2008; Col: Hermes F. de Medeiros". Two females paratypes labeled "Drosophila caxiuana Gottschalk et al. PARÁTIPO F / 

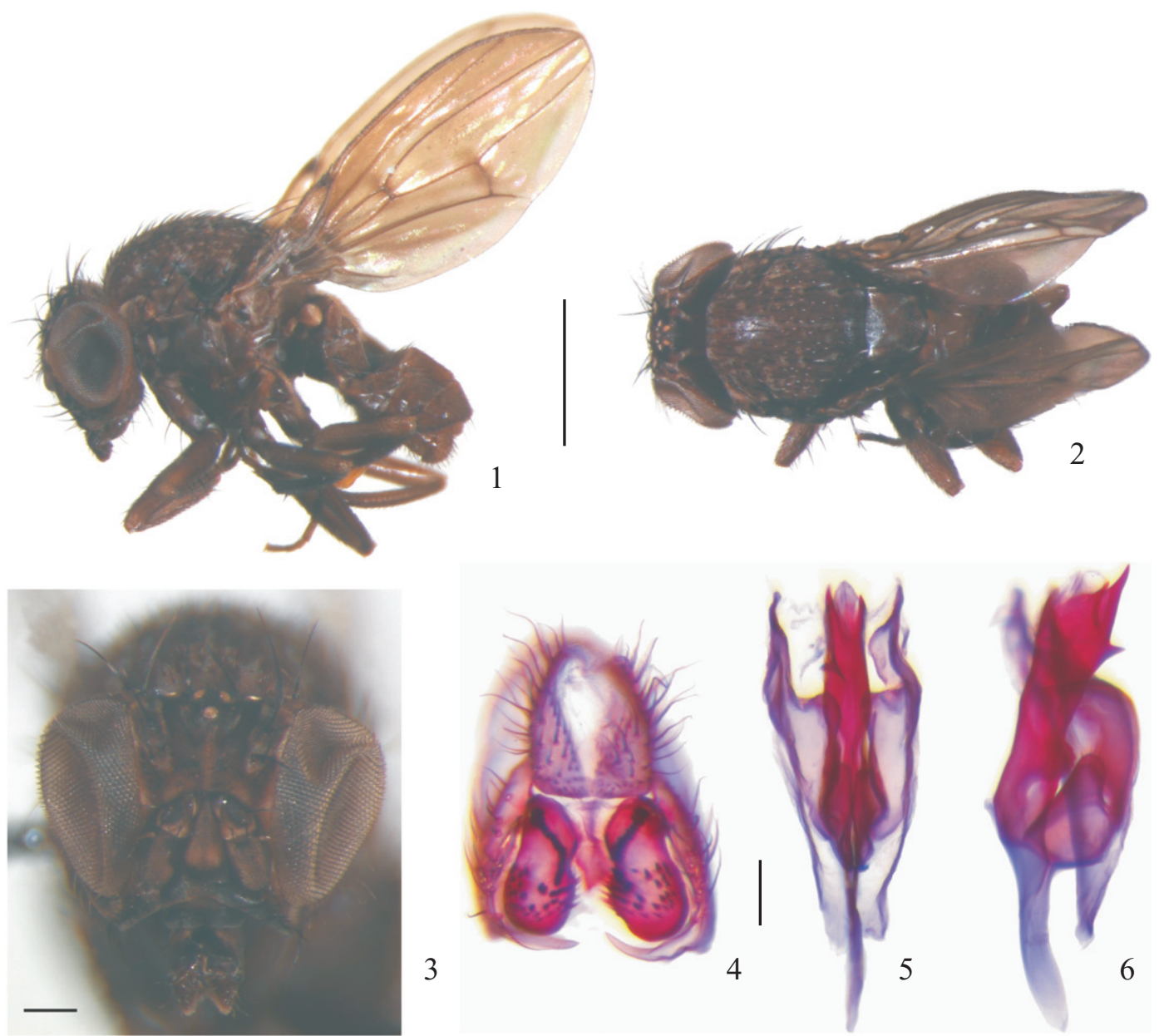

Figs. 1-6. Drosophila caxiuana sp. nov. 1-3, Habitus of a male paratype: 1, left lateral; 2, dorsal; 3, frontal view; 4-6, male terminalia of the holotype: 4, epandrium, cerci, surstyli and decasternum in posterior view; 5, aedeagus, aedeagal apodeme, hypandrium, paraphysis and gonopods ventral view; 6, aedeagus, aedeagal apodeme, hypandrium, paraphyses and gonopods in left lateral view. Scale bars: $1-2=1 \mathrm{~mm}, 3=0.2 \mathrm{~mm}, 4-6=0.1 \mathrm{~mm}$.

Brasil - PA - Portel; FLONA Caxiuanã - PPBio; 1 ${ }^{\circ} 57^{\prime} 36,76$ ”'S, 51³8'16,00”W; Código U07003; Data: 30.V.2008 a 03.VI2008; Col: Hermes F. de Medeiros". Postabdomen of the holotype, one male and one female paratypes dissected, stored in microvials with glycerin with the pinned specimens. Internal terminalia of one male paratype missed.

Type locality. Caquajó river, Portel, Pará, Brazil (1 ${ }^{\circ} 57^{\prime}$ 36.76”S, 51³8'16.00”W).

Diagnosis. Body color mainly brown; facial carina prominent, noselike, sulcate; scutum and scutellum grey with brown spots in the base of almost all setae or setulae, which may be fused; wings brown with clouded crossveins, $\mathrm{R}_{4+5}$ and $\mathrm{M}$ distally convergent; silvery yellow flagellomere; length of the first genal setae, about $1 / 3$ to $3 / 4$ of the vibrissa; arista with 11 branches (6 dorsal, 3 ventral plus the terminal fork); basal scutellars setae convergent; absence of prescutellar bristles; $\mathrm{C}$ index about 2.7-3.1; body length 3.0 to $3.3 \mathrm{~mm}$ in dried specimens; surstyli and decasternum as in Figs. 4 and 7-8; aedeagus, aedeagal apodeme and paraphysis as in Figs. 5-6 and 11-18.

Description. Male. Head. (Fig. 3) Predominantly blackish brown; width 1.34 (1.26-1.38) mm. Frons brown, covered with ca. 8 (6-9) interfrontal setulae and ca. 9 (7-11) setulae in the margin of ptilinal suture, frontal length 0.53 (0.49-0.63) mm; frontal index 1.09 (1.00-1.23), frontal tapering ratio 1.49 (1.44-1.55). Frontal triangle almost inconspicuous, gray brown to brown, velvety. Ocellar triangle dark brown and prominent, silky, 43\% (39-49\%) of frontal length. Frontal vittae dull reddish brown, dark brown in posterior half, with a silvery yellow thin stripe from ptilinal suture margin to frontal triangle, eyes margin and ptilinal suture margin silvery yellow. Orbital plates silvery yellow with a brown spot in the base of each orbital seta and vertical seta, spots in or3 and vtm larger than others, almost reaching the orbital plate margin. Orbital plates 85\% (69-97\%) of frontal length. Orbital setae dark brown, distance of or3 to or $148 \%$ (44-53\%) of or3 to vtm, or $1 /$ or3 ratio $0.87(0.83-0.91)$, or $2 /$ or1 ratio $0.70(0.66-0.74)$, postocellar setae $45 \%(32-54 \%)$ and ocellar setae $61 \%(51-68 \%)$ of frontal length, vt index 1.15 (1.02-1.32), vibrissal index 0.68 (0.37-0.84). Face brown. Carina conspicuous, broad below and medially sulcate, silvery yellow. Cheek index 7.51 (6.95-7.86). Eyes brownish (after dehydration); eye index 1.29 (1.25-1.35). Scape and pedicel silvery yellow, with a brown spot that cov- 
ers most of the segments; flagellomere silvery yellow; width/ length of flagellomere $0.58(0.50-0.67)$. Arista plumose, brown, lighter in base, with 6 dorsal branches, 3 ventral branches and 3 small inner branches, plus terminal fork. Proboscis brown, apex lighter. Palpus brown.

Thorax (Figs. 1-2) blackish brown; length 1.66 (1.58-1.71) $\mathrm{mm}$. Scutum and scutellum dull, silvery yellow with blackish brown spots fused to each other; 8 irregular rows of acrostichal setulae. $\mathrm{h}$ index $0.92(0.77-1.02)$, transverse distance of dorsocentral setae 2.36x (2.03-2.71) of longitudinal distance, dc index $0.73(0.72-0.74)$. No prescutellar setae. Distance between apical scutellar setae about $98 \%(95-105 \%)$ of that between apical and basal one; basal scutellar setae convergent; scut index $0.86(0.82-0.89)$. No proepisternal setae. Pleura predominantly blackish brown with silvery yellow sutures, sterno index $0.83(0.75-0.95)$, median katepisternal seta about $31 \%(26-42 \%)$ of anterior one. Halter silvery yellow with blackish brown spots. Legs blackish brown; femur and tibia with apical portion silvery yellow; tarsus silvery yellow. Protibia with apical setae, preapical setae on pro- and mesotibiae.

Wing (Fig. 1) brownish, margins slightly darker; R-M and $\mathrm{dM}-\mathrm{Cu}$ clouded; $\mathrm{R}_{4+5}$ and $\mathrm{M}$ convergent in apex; lappet conspicuous; length $2.64(2.57-2.71) \mathrm{mm}$, length to width ratio 2.16 (1.98-2.31). Indices: C, 2.86 (2.68-3.09); ac, 3.08 (2.823.29); hb, 0.70 (0.61-0.78); 4C, 0.85 (0.77-0.89); 4v, 1.66 (1.58-1.73); 5x, 0.97 (0.52-1.58); M, 0.35 (0.19-0.54); prox. $\mathrm{x}, 0.82(0.74-0.92)$.

Abdomen (Figs. 1-2) blackish brown; tergites with a thin silvery yellow marginal band reaching lateral margin.

Body length of the not dissected paratype (but dehydrated) $3.05 \mathrm{~mm}$.

Terminalia (Figs. 4-18). Epandrium (Figs. 4, 7) microtrichose in dorsal region and in the sides of the ventral lobes, ca. 20 lower setae, and no upper setae; less sclerotized in dorsal part. Ventral lobe well sclerotized, with two projections, the dorsal one covers partially the surstylus, the ventral one goes through below it. Cerci (Figs. 4, 7) partially fused to epandrium, microtrichose. Surstylus (Figs. 4, 7, 8) microtrichose only in lateral margin, strongly sclerotized, with a sinuate row of ca. 20 peg-like prensisetae, ca. 33 outer setae (ca. 21 peg-like and 12 bristle-like setae), and 8 inner setae. Decasternum as in Fig. 8. Hypandrium (Figs. 5, 6, 9, 10) as long as epandrium, longer than wide; posterior hypandrial process and dorsal arch absent; gonopod (Figs. 5, $6,9,10$ ) fused with hypandrium in posterior region; gonopod linked to paraphysis by a membranous tissue, without setae. Paraphysis (Figs. 5, 6, 11-18) parallel to aedeagus, with 3-4 setae in posterior distal region. Aedeagus (Figs. 5, 6, 11-18) fused to aedeagal apodeme, tube-shaped, bilaterally asymmetrical, with two pointed apical and one subapical processes, the subapical one oriented to left; 2 tiny spurs in the base of the apical smaller process; two winged processes in the base of aedeagus. Aedeagal apodeme shorter than aedeagus, laterally flattened. Ventral rod as long as the width of aedeagal apodeme in lateral view, slender.
Female. General aspects as in males, with exception of one female paratype with a face with a dull silvery yellow aspect. Measurements: Head width $1.40(1.39-1.42) \mathrm{mm}$. Frontal length 3.14 (3.02-3.26) $\mathrm{mm}$; frontal index $1.10(0.95-1.25)$; frontal tapering ratio $1.64(1.53-1.75)$. Ocellar triangle $50 \%$ (45-56\%) of frontal length. Orbital plates $83 \%$ of frontal length. Distance of or 3 to or $155 \%(53-57 \%)$ of or3 to vtm; or $1 /$ or 3 ratio $0.89(0.83-0.95)$; or $2 /$ or 1 ratio $0.68(0.65-0.70)$; postocellar setae $55 \%(50-60 \%)$ and ocellar setae $=55 \%(53-$ $57 \%$ ) of frontal length; vt index 1.00; vibrissal index 0.74 (0.62-0.86). Cheek index 6.20 (5.40-7.00). Eye index 1.20 (1.13-1.27). Flagellomere width/length 0.61 (0.59-0.63). Thorax length $1.83(1.75-1.90) \mathrm{mm}$. h index $0.88(0.83-0.90)$, transverse distance of dorsocentral setae $2.44 \mathrm{x}$ of longitudinal distance, dc index $0.71(0.59-0.82)$. Distance between apical scutellar setae $95 \%(90-100 \%)$ of the between apical and basal one; scut index 1.05, sterno index 0.83 (0.82-0.84), median katepisternal seta $22 \%(21-24 \%)$ of anterior one. Wing length 3.37 (3.35-3.38) mm, length to width ratio $=2.30(2.29-2.31)$. Indices: C, 2.93 (2.80-3.05); ac, 3.67 (3.33-4.00); hb, 0.73 (0.70-0.75); 4C, $0.76(0.74-0.78) ; 4 \mathrm{v}, 1.58$ (1.52-1.65); 5x, $0.90(0.80-1.00)$; M, $0.34(0.30-0.39)$; prox. $\mathrm{x}=0.89(0.81-$ $0.96)$. Body length of the paratypes dehydrated before dissection $3.14(3.02-3.26) \mathrm{mm}$.

Female terminalia (Fig. 19). Tergite VIII microtrichose dorsally and laterally, with ca. 9 setae in ventral margin. Epiproct and hypoproct trichose. Valve of oviscapt triangular, long, distally rounded, with ca. 1 peg-like roundish-tipped and 6 trichoid-like discal sensilla; ca. 19 marginal peg-like, roundish-tipped, outer sensilla; 3 trichoid-like thin dorsally subterminal and one long ventrally subterminal positioned inner ovisensilla. Spermathecal capsule (Fig. 20) large, warty, as long as wide, proximally rounded, weakly sclerotized; basal introvert around 3/4 the capsule length; apical introvert absent.

Etymology. The species name refers to its type locality, the National Forest of Caxiuanã.

Distribution. Known only from the type locality.

Relationships. Drosophila caxiuana sp. nov. belongs to the annulimana group of Drosophila subgenus by having a convex and spotted thorax, $\mathrm{R}_{4+5}$ and $\mathrm{M}$ converging at tip, and the base of or2 external and anteriorly to the base of or1 (Freire-Maia \& Pavan 1949); and by the characteristics of the epandrium, cerci and prensisetae of surstyli (see Hsu 1949). According to the male terminalia morphology, it is an atypical species in the group, by the lack of the following features: (1) the rigid and wrinkly apical prominence (present in D. annulimana Duda, 1927, D. araicas Pavan \& Nacrur, 1950, D. aracataca Vilela \& Val, 1983 and D. aragua Vilela \& Pereira, 1982); (2) wings in the dorsal cleft margins (present in D. annulimana, D. araicas, D. aracataca, D. aragua, D. arauna Pavan \& Nacrur, 1950, D. paratarsata Vilela, 1985, D. yana Vela \& Rafael, 2005, D. tarsata Schiner, 1868 and D. breuerae Rocha, 1971); and (3) a dorsoventrally flattened aedeagus (present in D. pseudotalamancana Pereira \& Vilela, 1987, D. arassari Cunha \& Frota-Pessoa in Pavan \& Cunha, 1947, D. arapuan Cunha \& Pavan in Pavan \& Cunha, 1947 and D. talamancana Wheeler, 1968). 

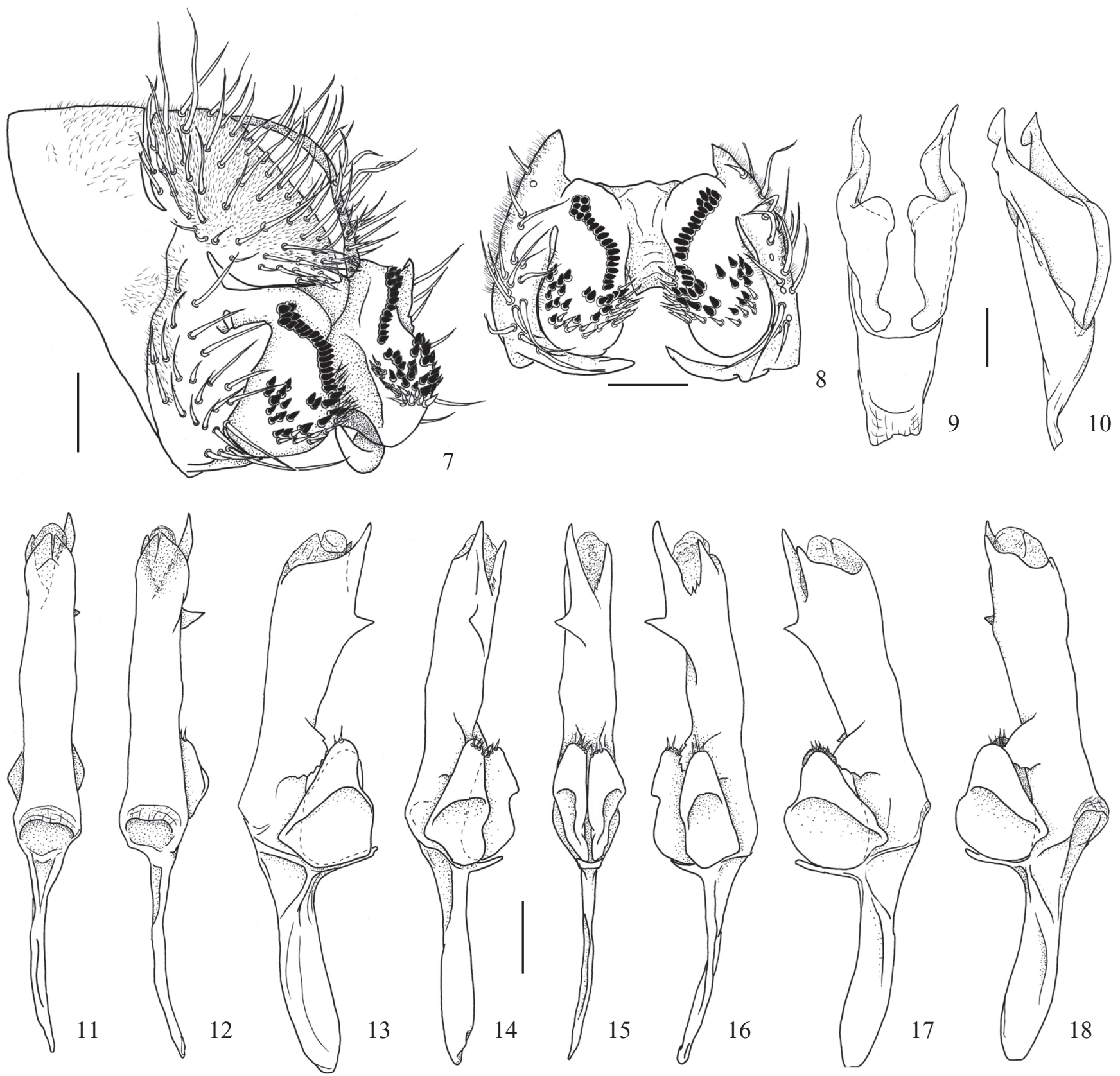

Figs. 7-18. Male terminalia of the holotype of Drosophila caxiuana sp. nov: 7 , epandrium, cerci, surstyli and decasternum in oblique posterior view; 8 , surstyli, decasternum and the ventral lobes of epandrium in posterior view; 9 , hypandrium and gonopods in ventral view; 10 , hypandrium and gonopods in left lateral view; 11-18, aedeagus, aedeagal apodeme and paraphyses in several views, from dorsal to right oblique dorsal view. Scale bar $=0.1 \mathrm{~mm}$

Drosophila schineri has also an atypical male terminalia within the $D$. annulimana group, by the shape of paraphysis and surstylus (Pereira \& Vilela 1987), and by a tubular aedeagus (as D. ararama and D. gibberosa Patterson \& Mainland in Patterson, 1943). Thus, the affinity of D. caxiuana sp. nov. with other species of the $D$. annulimana species group remains uncertain.

Drosophila caxiuana sp. nov. differs from D. annulimana, D. aracataca, D. aragua, D. ararama, D. arassari, D. breuerae, D. gibberosa, D. paratarsata, D. schineri, D. tarsata and D. yana by the silvery yellow flagellomere. It differs from $D$. aracataca, $D$. arapuan, $D$. ararama, $D$. arassari, D. breuerae and $D$. gibberosa by the length of the first genal setae, about $1 / 3$ to $3 / 4$ of the vibrissa. It differs from $D$. annulimana, $D$. aracataca, $D$. aragua, $D$. araicas, $D$. ararama, $D$. arauna, $D$. breuerae, D. gibberosa, D. paratarsata, D. pseudotalamancana, $D$. schineri, D. talamancana, D. tarsata and D. yana by the arista with 11 branches ( 6 dorsal, 3 ventral plus the terminal fork). It differs from $D$. arapuan, $D$. arassari, $D$. paratarsata and $D$. tarsata by the basal scutellars setae convergent; and 


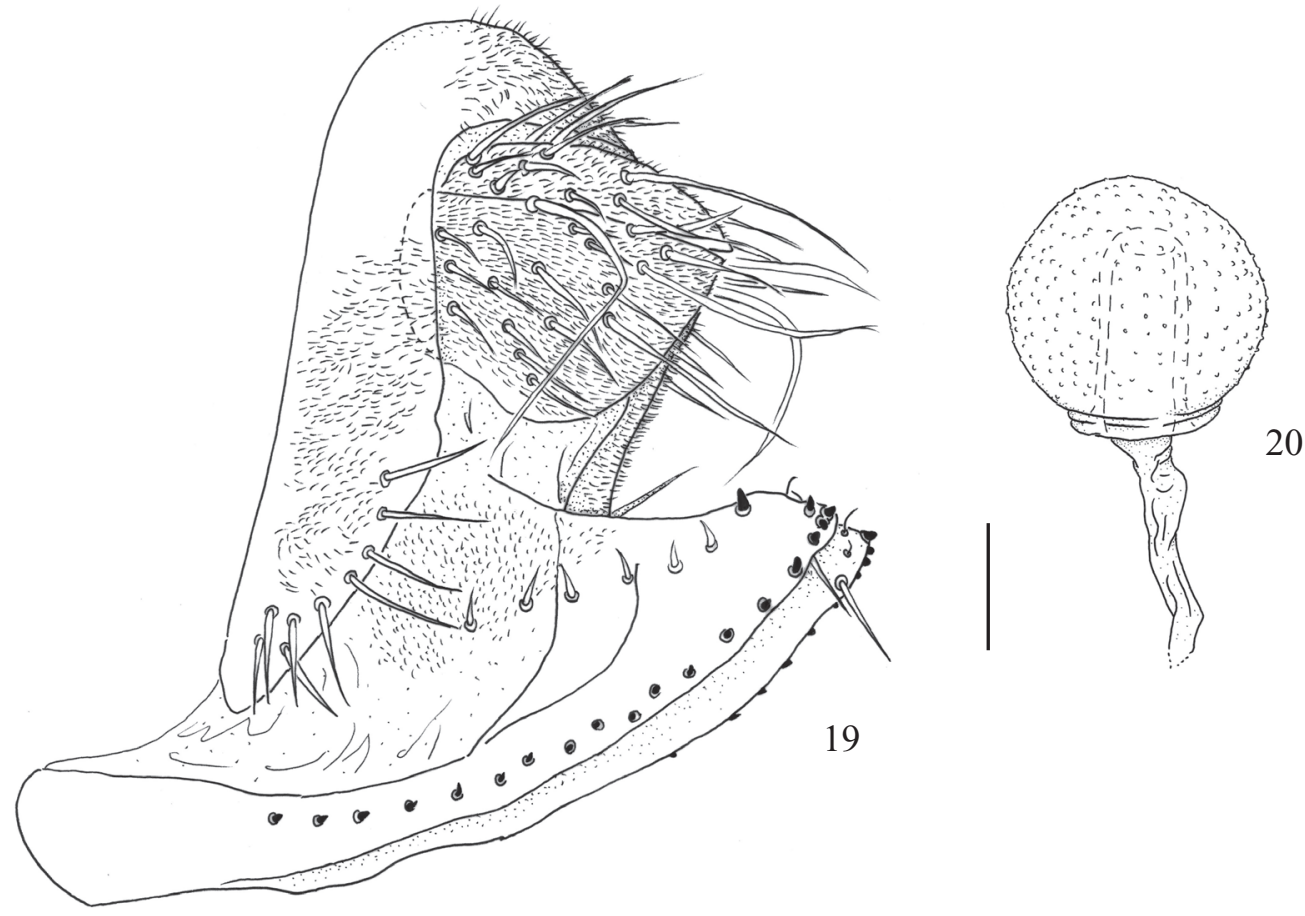

Figs. 19-20. Female terminalia of a Drosophila caxiuana sp. nov. paratype; 19, tergite VIII, epiproct, hypoproct, oviscapt valves, oblique posterior view; 20, inner spermathecal capsule. Scale bar $=0.1 \mathrm{~mm}$.

differs from $D$. annulimana, $D$. aracataca, D. aragua, $D$. araicas, $D$. arauna, $D$. paratarsata and $D$. tarsata by the absence of prescutellar bristles; $\mathrm{C}$ index about 2.7-3.1, while other species have $\mathrm{C}$ index higher than 3.0 (commonly higher than 3.5); body length 3.0 to $3.3 \mathrm{~mm}$ in dried specimens, while other species of the D. annulimana group have more than 3.4 $\mathrm{mm}$, commonly more than $4.0 \mathrm{~mm}$.

\section{ACKNOWLEDGEMENTS}

We thank to M.Sc. Jonas da Silva Döge and two anonymous referees for the valuable suggestions in the manuscript. This research was supported by the Conselho Nacional de Desenvolvimento Científico e Tecnológico (CNPq), Programa de Pesquisa em Biodiversidade (PPBio) Amazônia Oriental and Ministério da Ciência e Tecnologia (MCT), Brazil.

\section{REFERENCES}

Bächli, G.; C. R. Vilela; S. A. Escher \& A. Saura. 2004. The Drosophilidae (Diptera) of Fennoscandia and Denmark. Fauna Entomologica Scandinavica 39: 1-362.

Breuer, M. E. \& C. Pavan. 1950. Genitália masculina de "Drosophila” (Diptera): grupo "annulimana". Revista Brasileira de Biologia 10: 469-488.

Döge, J. S.; V. L. S. Valente \& P. R. P. Hofmann. 2008. Drosophilids (Diptera) from an Atlantic Forest area in Santa Catarina, Southern Brazil. Revista Brasileira de Entomologia 52: 615-624.

Freire-Maia, N. \& C. Pavan. 1949. Introdução ao estudo da Drosofila. Cultus 1: $5-71$

Received 21/1/2011; accepted 25/10/2012

Editor: Silvio Shigueo Nihei
Gottschalk, M. S.; D. C. De Toni, D.; V. L. S. Valente \& P. R. P. Hofmann 2007. Changes in Brazilian Drosophilidae (Diptera) assemblages across an urbanisation gradient. Neotropical Entomology 36: 848-862.

Hsu, T. C. 1949. The external genital apparatus of male Drosophilidae in relation to systematics. University of Texas Publication 4920: 80-142.

Martins, M. B. 2001. Guilds of Drosophilids on Forest Fragments, p. 175 186. In: R. O. Bierregaard, C. Gascon and T. E. Lovejoy (eds.). Lessons from Amazonia. The ecology and conservation of a fragmented forest. Yale, Yale University, $x v+478$ p.

Pereira, M. A. Q. R. \& C. R. Vilela. 1987. Two new members of the Drosophila annulimana species group (Diptera, Drosophilidae). Revista Brasileira de Entomologia 31: 13-18.

Tidon, R. 2006. Relationships between drosophilids (Diptera, Drosophilidae) and the environment in two contrasting tropical vegetations. Biological Journal of the Linnean Society 87: 233-247.

Vela, D. \& V. Rafael. 2005. Catorce nuevas especies del género Drosophila (Diptera, Drosophilidae) en el bosque húmedo montano del Volcán Pasochoa, Pichincha, Ecuador. Revista de Medicina y Ciencias Biológicas 27: $27-41$

Vilela, C. R. 1985. A new Peruvian species of Drosophila (Diptera, Drosophilidae) belonging to the annulimana group. Ciência e Cultura 37: $1961-1964$

Vilela, C. R. \& G. Bächli. 1990. Taxonomic studies on Neotropical species of seven genera of Drosophilidae (Diptera). Mitteilungen der Schweizerischen Entomologischen Gesellschaft/ Bulletin de la Société Entomologique Suisse 63 (Supplement): 1-332.

Vilela, C. R. \& M. A. Q. R. Pereira. 1985. Redescription of Drosophila talamancana Wheeler (Diptera, Drosophilidae). Revista Brasileira de Entomologia 29: 181-184.

Vilela, C. R. \& F. C. do Val. 1983. Redescription of Drosophila tarsata Schiner, 1868 and description of a new species, both in the annulimana group (Diptera, Drosophilidae). Revista Brasileira de Biologia 43: 373-380. 